\title{
KOMPOSISI VIGOR KECAMBAH TUSAM PADA BEBERAPA TINGKAT DEVIGORASI DAN KERAPATAN BENIH
}

\author{
The Composition of Tusam Sprouts Vigor on Several Devigoration and \\ Seed Density Levels
}

\author{
Asep Rohandi dan/and Nurin Widyani \\ Balai Penelitian Teknologi Perbenihan Bogor \\ Jl. Pakuan Ciheuleut PO. Box 105, Bogor - 16001 \\ Telp./Fax. (0251) 8327768
}

Naskah masuk : 16 Juni 2008; Naskah diterima : 15 Mei 2009

\begin{abstract}
A major problem encountered during seed procurement is low vigor of long term stored seed, affecting in turn the success of out planting. The objective of this study was to determine the effect of devigoration and density levels of tusam (Pinus merkusii) seeds on the sprouts vigor composition to support the nursery success. A completely randomized design with a single factor (i.e. seed densities) was used in this experiment. The density was arranged in 6 levels, which were predetermined based on the percentage of normal germinates of various seed lots. This variation was obtained through seed-ageing treatment at 6 durations, i.e. 0, 72, 120, 192, 216, and 240 hours (as devigoration levels). From each of those measured six levels seed density, thereby acquiring in all 6 densities ranging from 50 to 99 seeds per $600 \mathrm{~cm}^{2}$ area. It turned out that ageing treatment (devigoration levels) for 240 hours caused decrease in percentage by about $23 \%$ in comparison with the control (without ageing or at zero-hour ageing). Further, the different seed densities did not significantly affect vigor status of germinant, growth rate, growth uniformity/ simultanity, and delta value as well as the score-based nursery success. The decrease in seed vigor (devigoration) as much as 1920\% could be overcome by increasing density as much as 16 seeds per 600 $\mathrm{cm}^{2}$ area. In general, the germinant of tusam seeds still belonged to the normal criteria (N), i.e. strongly normal $(K)$ and less strong $(K K)$. This condition is suspected imply to the possibility of seed to survive in the field.
\end{abstract}

Key words: devigoration level, Pinus merkusii seeds, seed density, sprout, and growth

\begin{abstract}
ABSTRAK
Masalah utama yang dijumpai dalam pengadaan benih adalah rendahnya vigor, terutama ketika disimpan untuk jangka waktu lama, dengan demikian mempengaruhi kesuksesan penanaman benih di lapangan. Berkaitan dengan hal tersebut, penelitian ini dilakukan dengan tujuan untuk mengetahui pengaruh tingkat devigorasi dan kerapatan benih Pinus merkusii terhadap komposisi vigor kecambah untuk menunjang keberhasilan persemaian. Penelitian ini menggunakan rancangan acak lengkap dengan faktor tunggal (kerapatan benih). Kerapatan bervariasi dalam 6 taraf, yang didasarkan sebelum ditentukannya persentase dari benih normal yang tumbuh di berbagai lot benih. Variasi ini didapat lewat perlakuan enam taraf pengusangan (penderaan), yaitu $0,72,96,120,216$, dan 240 jam (sebagai taraf devigorasi). Dari masingmasing enam taraf tersebut diukur kerapatan benih, dengan demikian diperoleh kisaran antara 50-99 benih setiap $600 \mathrm{~cm}^{2}$. Sampai tingkat penderaan 240 jam terlihat bahwa terjadi penurunan persentase pertumbuhan semai sekitar 35\% jika dibandingkan dengan kontrol (tanpa penderaan). Lebih lanjut, kerapatan benih yang berbeda tidak berpengaruh nyata terhadap status vigor perkecambahan, kecepatan dan keserempakan berkecambah, nilai delta serta keberhasilan persemaian. Penurunan vigor benih (devigorasi) sebanyak 35\% masih dapat diatasi dengan meningkatkan kerapatan benih sebanyak 49 benih setiap $600 \mathrm{~cm}^{2}$. Secara umum, kecambah tusam masuk dalam kriteria normal (N), yaitu normal kuat (K) dan kurang kuat (KK). Dengan pengelompokan seperti ini, diduga bibit tersebut kemungkinan dapat hidup berkelanjutan atau tidak sebelum dilakukan penanaman di lapangan.
\end{abstract}

Kata kunci: benih Pinus merkusii, tingkat devigorasi, kerapatan benih, semai, dan pertumbuhan 


\section{PENDAHULUAN}

Pelaksanaan program reboisasi dan rehabilitasi lahan serta pembangunan hutan tanaman masih menghadapi beberapa kendala dan tantangan, salah satunya adalah penyediaan benih/bibit berkualitas dalam jumlah yang cukup dan berkesinambungan. Untuk memenuhi hal tersebut diperlukan pengetahuan yang cukup mengenai teknik silvikultur terutama untuk jenis yang akan dikembangkan. Salah satu jenis pohon yang sering digunakan untuk kegiatan reboisasi dan rehabilitasi lahan adalah jenis tusam (Pinus merkusii).

Salah satu contoh pentingnya pengaruh mutu benih terhadap keberhasilan kegiatan reboisasi adalah kurang berhasilnya kegiatan penanaman jenis tusam yang dilaksanakan pada tahun 1970-1980an dan diduga kuat terkait dengan rendahnya mutu fisiologis benih. Rendahnya mutu fisiologis benih tersebut antara lain ditunjukkan oleh hasil pengujian terhadap benih $P$. merkusii untuk kegiatan reboisasi yang dihasilkan dari Pasir Seuti (Mei 1983) dan Cimanong (Juni 1983), yang masing-masing hanya menunjukkan daya kecambah 53-58\%. Pengujian mutu benih asal Cililin, Bandung Selatan (Mei 1983) juga menunjukkan angka rendah, yaitu sekitar 39-53\% (Kartiko, 2000).

Sehubungan dengan hal di atas, untuk mengetahui mutu benih yang diproduksi dan yang akan digunakan perlu dilakukan pengujian mutu benih. Ada berbagai macam pengujian mutu benih yang meliputi pengujian daya berkecambah atau daya tumbuh dan pengujian vigor. Pengujian daya berkecambah atau daya tumbuh memberikan informasi tentang kemungkinan tanaman berproduksi normal dalam kondisi lapang dan lingkungan yang serba normal atau optimum (Sadjad, 1980; Anonim, 2004). Pengujian vigor merupakan pengujian perkecambahan yang biasa dilakukan di bawah kondisi yang kurang optimal atau di bawah cekaman seperti perlakuan penuaan dini (pengusangan) untuk mengetahui terjadinya kemunduran kualitas lot benih yang tidak nyata pada pengujian perkecambahan biasa (Anonim, 2004).

Permasalahan yang sering timbul dalam pengadaan benih kehutanan adalah vigor benih yang rendah, terutama jika disimpan dalam waktu yang cukup lama. Keadaan ini sangat mempengaruhi keberhasilan penanaman di lapangan. Untuk itu diperlukan penelitian mengenai kriteria vigor bibit/kecambah yang sampai saat ini masih jarang dilakukan untuk benih kehutanan.

Perkecambahan didefinisikan sebagai munculnya kecambah sampai pada struktur yang penting dapat berkembang lebih lanjut menjadi tanaman di bawah kondisi yang memadai dalam tanah (ISTA, 1996). Struktur benih tanaman tersebut berupa sistem perakaran, tunas pertumbuhan, kotiledon dan tunas pucuk. Perkecambahan benih juga merupakan salah satu indikator yang berkaitan dengan kualitas benih. Sehingga pengujian kecambah atau viabilitas harus menggambarkan kecambah yang potensial, yang jika dengan penanganan yang memadai harus merefleksikan hasil kecambah yang diharapkan pada saat berada di persemaian.

Pengamatan mengenai vigor bibit atau kecambah, penilaian terhadap komponen-komponen struktur vigor bibit atau kecambah seperti akar primer, akar sekunder, epikotil, hipokotil dan daun pertama sangatlah penting terutama jika kita ingin membedakan status vigor bibit yaitu bibit/kecambah yang tumbuh normal kuat, kurang kuat dan abnormal. Untuk membedakan status vigor bibit tersebut perlu kriteria tertentu sehingga dapat dilakukan pengelompokan secara tepat (Kartika, 1994). Dengan pengelompokan seperti itu dapat diketahui kemungkinan bibit tersebut dapat hidup berkelanjutan atau tidak sebelum dilakukan penanaman di lapangan.

Penelitian ini bertujuan untuk mengetahui pengaruh tingkat devigorasi dan kerapatan benih $P$. merkusii terhadap komposisi vigor kecambah untuk menunjang keberhasilan persemaian.

\section{BAHAN DAN METODE}

\section{A. Lokasi dan Waktu}

Penelitian ini dilaksanakan di laboratorium dan rumah kaca Balai Penelitian Teknologi Perbenihan (BPTP Bogor) dan dilakukan selama empat bulan dari bulan November 2003 sampai bulan Februari 2004. 


\section{B. Bahan dan Alat}

Bahan dan alat yang digunakan adalah benih yang merupakan campuran (komposit) P. merkusii yang berasal dari Parungpanjang-Bogor, Kalimantan Selatan dan Sumatera Selatan, kertas merang, alkohol, media perkecambahan (tanah dan pasir), alat untuk pengusangan, bak plastik, kain kasa, bak kecambah berukuran $600 \mathrm{~cm}^{2}$, sprayer, alat ukur, kantong plastik/polybag, bambu dan plastik naungan.

\section{Prosedur Penelitian}

Prosedur penelitian yang dilakukan meliputi persiapan penelitian dan pelaksanaan penelitian yang diuraikan di bawah ini.

Persiapan yang dilakukan dalam penelitian ini adalah :

a. Seleksi benih

Seleksi benih dilakukan secara manual yaitu dengan memilih penampilan benih yang bagus, tidak keriput, keras dan sudah masak baik secara fisik maupun fisiologis.

b. Percobaan pendahuluan

Percobaan pendahuluan dilakukan untuk mengetahui cara pemecahan dormansi dan lamanya pengusangan benih P. merkusii.

c. Pengusangan (penderaan)

Pengusangan bertujuan untuk mendapatkan variasi vigor benih. Cara pengusangan yaitu benih dimasukkan di dalam wadah plastik yang telah diberi kawat kasa dan diisi air sebanyak $150 \mathrm{ml}$ kemudian ditutup dan air yang berada dalam wadah tidak mengenai benih. Wadah tersebut kemudian diletakan dalam inkubator dengan suhu $40^{\circ} \mathrm{C}$. Faktor pengusangan terdiri dari 6 taraf, yaitu $0,72,96$, 120, 216 dan 240 jam.

Pelaksanaan penelitian ini menggunakan dua eksperimen, yaitu :

1. Pembedaan tingkat devigorasi (kemunduran benih)

Langkah-langkah yang dilakukan adalah sebagai berikut:

a. Benih P. merkusii diberi perlakuan devigorasi dengan pengusangan $(0,72,96,120,216$ dan 240 jam). Pengusangan tersebut dilakukan untuk mendapatkan ragam lot benih.

b. Selanjutnya benih tersebut disemai pada campuran media tanah dan pasir dengan perbandingan 1:1 $(\mathrm{v} / \mathrm{v})$ di bak kecambah.

c. Penghitungan daya berkecambah benih $(\mathrm{N})$ untuk masing-masing taraf pengusangan.

2. Penentuan kerapatan benih

Penentuan kerapatan benih dilakukan berdasarkan data hasil pengamatan pada eksperimen tahap pertama dengan langkah-langkah sebagai berikut:

a. Setelah diperoleh data daya berkecambah benih (N0, N1, N2, N3, N4, N5), maka diperoleh informasi kerapatan benih yang akan digunakan. Penentuan kerapatan benih dihitung berdasarkan pada kelipatan nisbah bibit yang tumbuh normal setiap lot $(\mathrm{N})$ terhadap kontrol. Jika kerapatan benih yang umum dilakukan yaitu 100 butir per $1200 \mathrm{~cm}^{2}$, maka kerapatan benih $(d)$ yang digunakan dalam penelitian ini adalah (Kartika, 1994) :

$$
\begin{aligned}
d 0 & =50 \text { butir } / 600 \mathrm{~cm}^{2}\left(600 \mathrm{~cm}^{2} \text { adalah ukuran bak kecambah }\right) \\
d 1 & =\frac{\mathrm{N} 0}{\mathrm{~N} 1} \times d 0 \\
d 2 & =\frac{\mathrm{N} 0}{\mathrm{~N} 2} \times d 0 \\
d 3 & =\frac{\mathrm{N} 0}{\mathrm{~N} 3} \times d 0 \\
d 4 & =\frac{\mathrm{N} 0}{\mathrm{~N} 4} \times d 0 \\
d 5 & =\frac{\mathrm{N} 0}{\mathrm{~N} 5} \times d 0
\end{aligned}
$$


b. Jumlah benih yang dibutuhkan didasarkan pada kerapatan benih yang sudah ditentukan (pada butir c di atas). Benih tersebut selanjutnya diusangkan sesuai dengan tingkat/taraf pengusangan yang digunakan.

c. Benih disemai pada bak-bak kecambah yang sudah tersedia. Bak-bak kecambah yang sudah ditanami disimpan di rumah kaca sesuai dengan rancangan yang digunakan.

Keberhasilan persemaian diuji berdasarkan tolok ukur nilai delta (D) sebagai berikut (Kartika, 1994) :

$$
\mathrm{D}=\frac{\mathrm{KK}}{\mathrm{T}} \times 100 \% \times \frac{\mathrm{A} \times \mathrm{M}}{\mathrm{K}}
$$

dimana :

$$
\begin{aligned}
\mathrm{KK} & =\text { jumlah bibit yang tumbuh normal kurang kuat } \\
\mathrm{T} & =\text { jumlah contoh bibit } \\
\mathrm{A} & =\text { jumlah bibit abnormal } \\
\mathrm{M} & =\text { jumlah bibit yang mati } \\
\mathrm{K} & =\text { jumlah bibit yang tumbuh normal kuat }
\end{aligned}
$$

Untuk menghitung keberhasilan persemaian digunakan pendekatan fungsi (Kartika, 1994) :

$\mathrm{S}=\mathrm{f}(\mathrm{K}, \mathrm{D}-1, \mathrm{~T}-1)$

Keberh אूilan persemaiakr ditentukan dengan rumus (Kartika, 1994):

$$
\mathrm{S}=\frac{\mathrm{D} \times \mathrm{T}}{\mathrm{D}} \times 100 \% \times \frac{\mathrm{M}}{\mathrm{A} \times \mathrm{M}}
$$

dimana :

$$
\begin{array}{ll}
\mathrm{S} & =\text { keberhasilan persemaian } \\
\mathrm{KK} & =\text { jumlah bibit yang tumbuh normal kurang kuat } \\
\mathrm{T} & =\text { jumlah contoh bibit } \\
\mathrm{A} & =\text { jumlah bibit abnormal } \\
\mathrm{M} & =\text { jumlah bibit yang mati } \\
\mathrm{K} & =\text { jumlah bibityang tumbuh normal kuat } \\
\mathrm{D} & =\text { tolok ukur nilai delta }
\end{array}
$$

Pengamatan perkecambahan dilakukan setiap hari sampai tidak ada lagi kecambah yang tumbuh yaitu dengan mencatat jumlah kecambah normal yang tumbuh. Parameter yang diamati adalah daya berkecambah, kecepatan berkecambah dan keserempakan berkecambah. Perhitungan ini dihitung

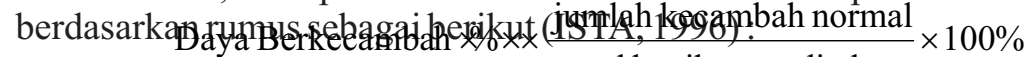
total benih yang ditabur

$$
\frac{\mathrm{N} 1}{\mathrm{D} 1} \times \frac{\mathrm{N} 2}{\mathrm{D} 2} \times \ldots \ldots \ldots \times \frac{\mathrm{Nn}}{\mathrm{Dn}}
$$

$\operatorname{KcT}(\% /$ hari $)=$

$$
\text { KsT } \% \times \times \frac{\text { jumlah kecambah normal kuat }}{\text { jumlah benih yang ditanam }} \times 100 \%
$$

dimana :

$$
\begin{array}{ll}
\text { KcT } & =\text { kecepatan berkecambah } \\
\mathrm{N} 1 \ldots . . \mathrm{Nn} & =\text { kecambah normal } 1,2 \ldots . . \mathrm{N} \text { dalam } \% \\
\mathrm{D} 1 \ldots . \mathrm{Dn} & =\text { jumlah hari setelah tanam } \\
\text { KsT } & =\text { keserempakan berkecambah }
\end{array}
$$

Penelitian ini menggunakan Rancangan Acak Lengkap (RAL) satu faktor dengan tiga kali 
ulangan. Sebagai faktor adalah kerapatan benih (jumlah per satuan luas) di persemaian yang terdiri dari 6 taraf/tingkat $(\mathrm{d} 0, \mathrm{~d} 1, \mathrm{~d} 2, \mathrm{~d} 3, \mathrm{~d} 4, \mathrm{~d} 5)$ yang ditentukan atas dasar persentase bibit normal dari lot benih yang beragam. Ragam lot benih didapatkan dengan perlakuan pengusangan/penderaan sebanyak 6 tingkat $(0$, 72, 96, 120, 216 dan 240 jam).

Pengolahan data menggunakan SAS Procedure GLM (Anonim, 1985). Untuk membedakan pengaruh kerapatan atau devigorasi terhadap peubah yang diamati maka dilakukan sidik ragam dan uji DMRT pada taraf $5 \%$. Model liniernya adalah :

$$
\begin{aligned}
\mathrm{Y}_{\mathrm{ijk}} & =\text { pengamatan pada tingkat kerapatan ke- } \mathrm{i} \\
\times & =\text { rata-rata umum } \\
\mathrm{A}_{\mathrm{i}} & =\text { pengaruh perlakuan kerapatan ke- } \mathrm{i} \\
\mathrm{x}_{\mathrm{ijk}} & =\text { galat percobaan }
\end{aligned}
$$

\section{HASIL DAN PEMBAHASAN}

\section{A. Perbedaan tingkat devigorasi (kemunduran benih)}

Hasil yang diperoleh dari perlakuan penderaan benih P. merkusii adalah terjadinya penurunan vigor awal benih dengan makin lamanya tingkat pengusangan. Hasil pengamatan daya berkecambah dan perhitungan kerapatan pada setiap tingkat pengusangan benih $P$. merkusii dalam penelitian ini dapat dilihat pada Tabel 1.

Tabel (Table) 1. Hasil pengamatan kadar air, daya berkecambah dan perhitungan kerapatan pada setiap tingkat pengusangan benih $P$. merkusii (The result of observation on moisture content, germination capacity and the density of each seed-ageing level of P. merkusii)

\begin{tabular}{|c|l|c|c|c|c|c|c|}
\hline \multirow{2}{*}{ No. } & \multicolumn{1}{|c|}{ Parameter } & \multicolumn{5}{|c|}{ Lama Pengusangan (jam) / Ageing Period (hour) } \\
\cline { 3 - 8 } & $\begin{array}{c}0 \\
(\mathrm{~N} 0)\end{array}$ & $\begin{array}{c}72 \\
(\mathrm{~N} 1)\end{array}$ & $\begin{array}{c}96 \\
(\mathrm{~N} 2)\end{array}$ & $\begin{array}{c}120 \\
\text { (N3) }\end{array}$ & $\begin{array}{c}216 \\
\text { (N4) }\end{array}$ & $\begin{array}{c}240 \\
\text { (N5) }\end{array}$ \\
\hline 1. & Kadar Air / Moisture Content (\%) & 7.3 & 14.5 & 18.9 & 18.3 & 19.0 & 16.2 \\
\hline 2. & $\begin{array}{l}\text { Daya Berkecambah / Germination } \\
\text { Capacity (\%) }\end{array}$ & 71 & 67 & 53 & 47 & 42 & 36 \\
\hline 3. & $\begin{array}{l}\text { Kerapatan / Density (butir/bak } \\
\text { kecambah) }\end{array}$ & 50 & 53 & 67 & 76 & 85 & 99 \\
\hline
\end{tabular}

Perbedaan karakter benih memberikan persentase vigor awal kecambah yang berbeda. Pada tingkat penderaan 240 jam terlihat bahwa daya berkecambah benih $P$. merkusii mengalami penurunan sebesar 35\% dari kontrol (tanpa penderaan). Kondisi tersebut berbeda dengan benih Acacia crassicarpa dimana pada tingkat penderaan yang sama vigor awal kecambah hanya menurun sebesar $19 \%$ (Rohandi dan Widyani, 2007). Hal ini diduga disebabkan karena struktur kulit benih P. merkusii lebih lunak sehingga menyebabkan kerusakan benih menjadi lebih cepat. Zanzibar (2003) menjelaskan terjadinya perbedaan penurunan daya berkecambah pada beberapa tingkat penderaan. Daya berkecambah benih Paraserianthes falcataria cenderung semakin menurun dengan semakin lamanya waktu penderaan, sedangkan untuk jenis Acacia mangium pada tingkat penderaan 480 jam tidak memberikan pengaruh yang nyata terhadap daya kecambah benih. Hal ini menunjukkan bahwa lama penderaan yang diujikan belum efektif untuk jenis ini. 


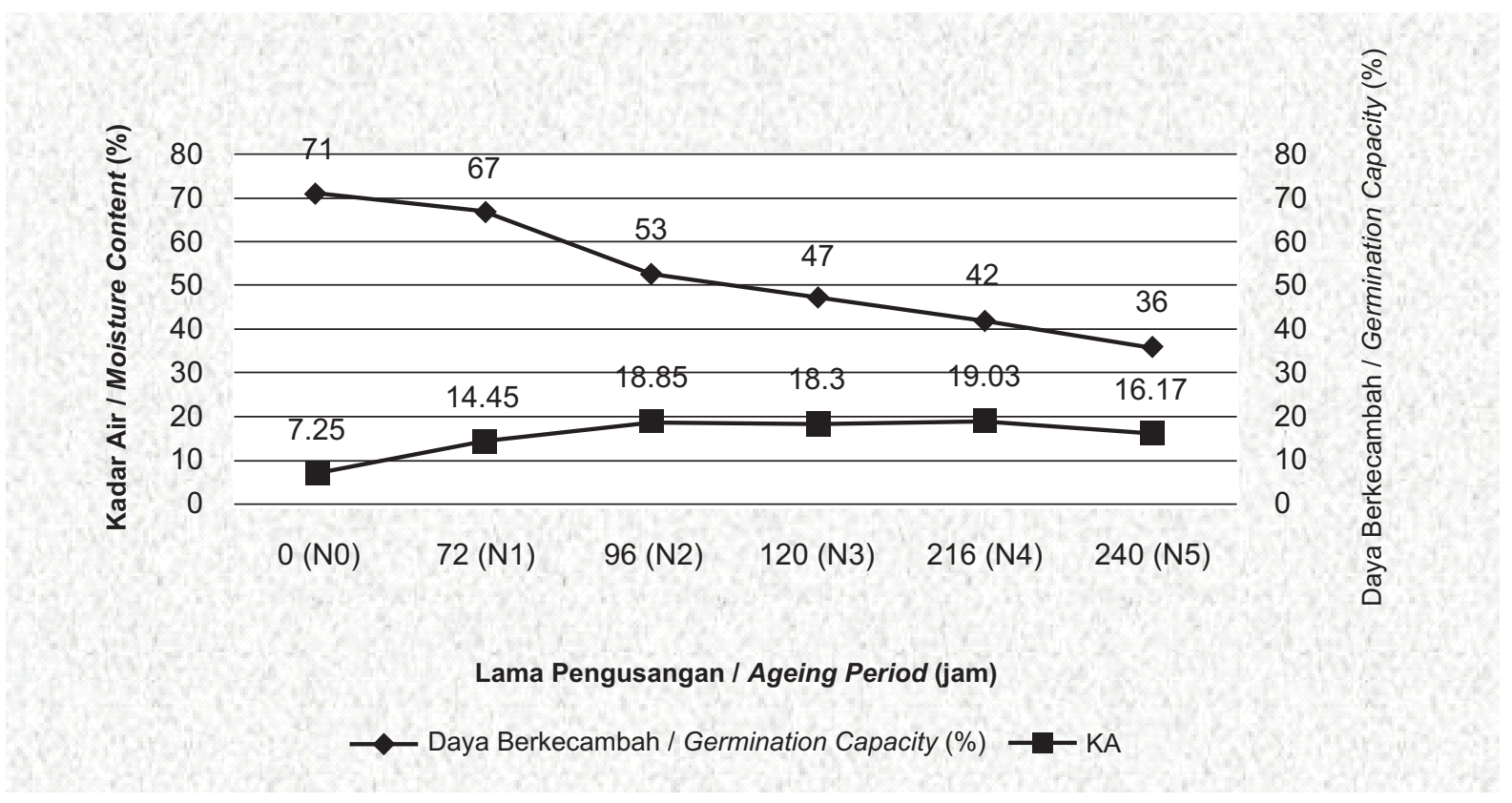

Gambar(Figure) 1. Daya Berkecambah dan kadar air benih P. merkusii (Germination capacity and moisture content of P. merkusii seed)

Persentase vigor benih pada benih $P$. merkusii menunjukkan bahwa makin lama pengusangan makin menurun persentasenya, walaupun penurunan yang terjadi tidak drastis (Gambar 1). Penurunan ini menandakan terjadinya kemunduran benih. Kemunduran benih merupakan semua perubahan yang terjadi dalam benih yang berperan dan akhirnya mengarah pada kematian benih (Byrd, 1983). Kemunduran benih yang terjadi juga menandakan turunnya kualitas atau viabilitas benih yang mengakibatkan rendahnya vigor dan jeleknya pertumbuhan tanaman serta produksinya (Sutopo, 1995).

Berbeda dengan daya berkecambah (Gambar 1), kadar air benih cenderung meningkat dengan semakin lamanya waktu pengusangan. Hal tersebut disebabkan oleh kondisi suhu dan kelembaban di sekitar benih (inkubator) yang cukup tinggi. Dengan demikian, benih mengalami imbibisi yang berasal dari uap air di dalam inkubator. Sutopo (2002) menjelaskan bahwa benih yang bersifat higroskopis sangat mudah menyerap air dari udara di sekitarnya. Kandungan air yang tinggi meningkatkan kegiatan enzimenzim sehingga mempercepat terjadinya proses respirasi. Perombakan cadangan makanan berlangsung cepat yang akhirnya benih akan kehabisan bahan bakar pada jaringan-jaringan yang penting (meristem) sehingga cepat mengalami kemunduran.

Menurunnya daya kecambah benih merupakan salah satu perubahan fisiologi dari kemunduran benih. Kemunduran benih pada benih yang diuji terjadi akibat perlakuan yang diberikan pada benih yaitu lamanya penderaan, dimana makin lama pengusangan maka daya kecambah benih menurun. Kemunduran benih yang terjadi secara fisiologis diindikasikan dengan adanya perubahan warna benih, tertundanya perkecambahan, menurunnya toleransi terhadap kondisi simpan yang kurang sesuai, peka terhadap radiasi, menurunnya pertumbuhan kecambah dan meningkatnya pertumbuhan kecambah abnormal (Blanche et al., 1991; Abdul Baki \& Anderson, 1970; Anderson, 1970).

Berdasarkan persentase vigor kecambah (Tabel 1), maka didapatkan kerapatan masing-masing benih setiap bak kecambah. Hasil perhitungan menunjukkan bahwa semakin rendah persentase vigor kecambah maka kerapatan benih $P$. merkusii lebih rapat per bak kecambah. Diharapkan penurunan vigor benih dapat diatasi dengan peningkatan kerapatan benih untuk meningkatkan jumlah kecambah normal kuat yang akan digunakan untuk kegiatan penanaman selanjutnya. Untuk membuktikan hal tersebut maka dilakukan percobaan pengaruh kerapatan benih P. merkusii terhadap vigor kecambah. 


\section{B. Pengaruh kerapatan benih P. merkusii terhadap vigor kecambah}

Vigor benih dapat diartikan sebagai kapasitas benih yang dapat menentukan potensi kemunculan dan perkembangan semai secara normal, cepat dan seragam pada kondisi lapangan yang beragam (Anonim, 2004). Berdasarkan hasil penelitian awal, maka dilakukan penanaman dengan kerapatan (jumlah persatuan luas) yang berbeda yang menghasilkan status vigor kecambah pada benih yang diuji. Menurut Gardner et al. (1991), pengaturan kerapatan tanaman dan distribusinya di permukaan tanah dilakukan untuk memperluas daun sehingga penyerapan energi matahari menjadi efisien serta terdistribusi merata untuk mendukung pertumbuhan secara optimal. Pengamatan vigor kecambah untuk jenis $P$. merkusii tersebut dilakukan pada umur 9 minggu.

Data hasil pengamatan menunjukkan bahwa kerapatan benih tidak berbeda nyata terhadap semua parameter yang diamati. Hasil tersebut berarti bahwa penambahan jumlah benih terhadap kontrol dengan meningkatkan kerapatan benih saat penaburan untuk mengatasi penurunan vigor (devigorasi) pada semua taraf pengujian masih dapat dilakukan. Penurunan vigor benih tertinggi dari d0 (71\%) menjadi d5 (36\%) sebesar 35\% masih dapat diatasi dengan peningkatan kerapatan benih 49 butir/bak kecambah atau 98\% dari densitas benih yang umum dilakukan yaitu 50 butir/bak kecambah. Kartika (1994) melaporkan bahwa penurunan vigor benih Paraserianthes falcataria sebesar 10,66\% dapat diatasi dengan peningkatan densitas benih sebesar 14\%, sedangkan penurunan vigor benih Acacia mangium sebesar $10,67 \%$ masih dapat diatasi dengan peningkatan densitas benih sebesar 14\%. Hasil penelitian Rohandi dan Widyani (2007) menunjukkan bahwa penurunan vigor benih Acacia crassicarpa sebesar 19\% dapat diatasi dengan peningkatan densitas benih sebanyak 16 butir/bak kecambah (32\%). Sementara itu, Saptono (1988) melaporkan bahwa penambahan jumlah benih kedelai yang ditanam dapat digunakan untuk mengatasi penurunan produksi akibat menurunnya status vigor benih sampai $63 \%$ sepanjang kondisi lingkungan optimum. Komposisi vigor kecambah masing-masing perlakuan selengkapnya tercantum pada Tabel 2 .

Tabel (Table) 2. Rata-rata jumlah populasi bibit normal kuat (K), normal kurang kuat (KK), abnormal (A) dan mati $(\mathrm{M})$ (The average of population of normal strong $(K)$, less strong $(K K)$,

\begin{tabular}{|c|c|c|c|c|c|}
\hline \multirow{2}{*}{ No. } & Kerapatan Benih / & \multicolumn{4}{|c|}{ Status Vigor Kecambah / Seedling's Vigor Status (\%) } \\
\cline { 3 - 6 } & Sensity & $\mathrm{K}$ & $\mathrm{KK}$ & $\mathrm{A}$ & $\mathrm{M}$ \\
\hline 1. & $\mathrm{~d} 0$ & 73,31 & 21,14 & 5,56 & 0 \\
\hline 2. & $\mathrm{~d} 1$ & 69,41 & 28,29 & 2,30 & 0 \\
\hline 3. & $\mathrm{~d} 2$ & 62,11 & 35,10 & 2,79 & 0 \\
\hline 4. & $\mathrm{~d} 3$ & 68,00 & 31,12 & 0,88 & 0 \\
\hline 5. & $\mathrm{~d} 4$ & 70,63 & 26,34 & 3,03 & 0 \\
\hline 6. & $\mathrm{~d} 5$ & 79,27 & 19,37 & 1,36 & 0 \\
\hline
\end{tabular}

Data pada Tabel 2 menunjukkan bahwa dari populasi kecambah yang diamati, secara umum status vigor kecambah masuk dalam kriteria normal (N) yaitu Normal Kuat (K) dan Normal Kurang Kuat (KK). Hal ini menunjukkan perlakuan kerapatan cenderung tidak berbeda nyata terhadap persentase status vigor kecambah. Presentase kecambah normal kuat (K) P. merkusii cenderung lebih besar dibanding kecambah normal kurang kuat (KK) yaitu untuk seluruh kerapatan. Penampilan kecambah sebagian besar mempunyai diameter leher akar cukup besar, apabila kondisi ini terus bertahan sampai umur sapih, maka diprediksikan pada penanaman di lapangan tingkat keberhasilannya akan lebih tinggi karena bagian tersebut cenderung mempunyai cadangan makanan yang lebih banyak (Duryea, 1984).

Hasil sidik ragam (Lampiran 1) menunjukkan bahwa perbedaan perlakuan kerapatan benih tidak berpengaruh nyata terhadap status vigor kecambah, nilai delta dan keberhasilan persemaian untuk $P$. merkusii. Kemungkinan hal ini disebabkan pada semua tingkat kerapatan kecambah masih dapat mengambil nutrisi untuk mencukupi kebutuhan hidupnya. Pada jenis $P$. merkusii perlakuan kerapatan benih berpengaruh nyata terhadap status vigor kecambah Normal Kuat (K) dan Normal Kurang Kuat (KK). Proses pengambilan nutrisi pada tingkat kerapatan lebih rendah cenderung menghasilkan 
persentase kecambah normal kuat yang lebih besar dibanding pada tingkat kerapatan yang tinggi. Pada tingkat kerapatan rendah pengambilan nutrisi akan lebih optimal karena persaingan yang relatif sedikit. Gardner et al. (1991) menjelaskan bahwa peningkatan kerapatan tanaman menyebabkan batang tanaman menjadi lebih kecil, lebih lemah dan seringkali lebih tinggi. Jadi kerapatan tanaman untuk kultivar yang berbatang kokoh harus diturunkan untuk mengurangi jatuh rebah (robohnya atau tumbangnya tanaman). Meningkatnya kerapatan tanaman juga dapat menyebabkan bunga dan buah yang potensial tidak jadi (gugur) karena kompetisi antar tanaman semakin meningkat sehingga hasil panen per tanaman akan menurun.

Hasil penelitian Hamid (2004) menunjukkan bahwa penggunaan benih padi dengan kerapatan lebih rendah yaitu $30,40,50 \mathrm{~kg} / \mathrm{ha}$ menghasilkan produksi yang lebih tinggi dibandingkan dengan jumlah benih $60,70,80 \mathrm{~kg} / \mathrm{ha}$ yang disebabkan oleh letak benih yang ditebar lebih renggang sehingga tanaman lebih leluasa memperoleh hara, udara dan cahaya matahari. Padi dengan kerapatan rendah menghasilkan pertumbuhan anakan cukup banyak dengan malai yang cukup panjang dan besar, sedangkan penanaman dengan kerapatan tinggi menyebabkan tanaman menjadi kerdil, anakan kurang dan banyak mati sebelum terbentuk malai.

Meskipun semua kerapatan benih tidak berpengaruh terhadap vigor kecambah, tetapi pada tingkat kerapatan yang tinggi dijumpai sebagian tanaman yang mengalami kematian karena dumping off seperti juga yang terjadi pada benih krasikarpa (Rohandi dan Widyani, 2007). Kondisi demikian disebabkan oleh tingkat kelembaban yang cukup tinggi. Air yang berlebihan hampir selalu merusak karena air akan cenderung menggantikan udara sehingga akan terjadi pemadatan yang akan membatasi respirasi. Kelebihan air akan mendorong perkembangan penyakit yang disebabkan oleh jamur dumping off (Schmidt, 2000). Dumping off juga dapat terjadi apabila ada patogen yang terbawa oleh benih dan menjadi aktif segera setelah benih disebar atau disemaikan sehingga benih menjadi busuk sebelum atau sesudah benih berkecambah (Sutopo, 2002). Hal ini perlu menjadi pertimbangan dalam aplikasi di lapangan.

Nilai keberhasilan persemaian (S) dan nilai delta (D) didapatkan setelah kecambah siap sapih. Pada tahap ini perbedaan bentuk fisik atau penampilan kecambah dapat terlihat dari karakteristik morfologisnya yang merupakan salah satu kriteria kualitas bibit. Nilai delta dan keberhasilan persemaian untuk masing-masing perlakuan disajikan pada Tabel 3.

Tabel (Table) 3. Pengaruh kerapatan benih terhadap rata-rata kecepatan tumbuh (KcT), keserempakan tumbuh (KsT), Nilai delta (D) dan keberhasilan persemaian (S) (Effect of seed density on the average of growth rate, growth simultanity, delta value and the score-based nursery success)

\begin{tabular}{|c|c|c|c|c|c|}
\hline \multirow{2}{*}{ No. } & Kerapatan Benih/ & \multicolumn{4}{|c|}{ Parameter } \\
\cline { 3 - 6 } & Seed Density & KcT (\%/hari) & KsT (\%) & D (\%) & S (\%) \\
\hline 1. & $\mathrm{~d} 0$ & $3.20 \mathrm{~b}$ & $24.67 \mathrm{a}$ & $0.014 \mathrm{a}$ & $0.053 \mathrm{a}$ \\
2. & $\mathrm{~d} 1$ & $3.46 \mathrm{ab}$ & $23.27 \mathrm{a}$ & $0.011 \mathrm{a}$ & $0.270 \mathrm{a}$ \\
3. & $\mathrm{~d} 2$ & $3.85 \mathrm{ab}$ & $24.38 \mathrm{a}$ & $0.015 \mathrm{a}$ & $2.763 \mathrm{a}$ \\
4. & $\mathrm{~d} 3$ & $3.32 \mathrm{ab}$ & $25.88 \mathrm{a}$ & $0.006 \mathrm{a}$ & $1.613 \mathrm{a}$ \\
5. & $\mathrm{~d} 4$ & $3.46 \mathrm{ab}$ & $30.59 \mathrm{a}$ & $0.013 \mathrm{a}$ & $0.163 \mathrm{a}$ \\
6. & $\mathrm{~d} 5$ & $4.18 \mathrm{a}$ & $36.02 \mathrm{a}$ & $0.003 \mathrm{a}$ & $1.203 \mathrm{a}$ \\
\hline
\end{tabular}

Keterangan(Remarks): Angka-angka yang diikuti oleh huruf yang sama pada kolom yang sama tidak berbeda nyata pada tingkat kepercayaan 95\% uji berganda Duncan (values in columns with the same letter are not significantly different at $95 \%$ confident level in accordance the Duncan's multiple range test)

Dari Tabel 3 terlihat bahwa kecepatan tumbuh, keserempakan tumbuh, nilai delta dan nilai keberhasilan persemaian cenderung tidak berbeda nyata pada Uji Duncan. Apabila dilihat dari kecepatan tumbuh, perlakuan pada kerapatan rendah (d0) memiliki nilai terkecil dibanding perlakuan-perlakuan lainnya walaupun secara keseluruhan dalam uji Duncan tidak berbeda nyata. Sedangkan pada nilai delta, dengan semakin lama tingkat devigorasi maka nilai delta cenderung semakin menurun dimana pada perlakuan kerapatan d5 didapatkan nilai delta terkecil. Hasil berbeda dilaporkan oleh Kartika (1994) pada benih Paraserianthes falcataria dan Acacia mangium menunjukkan bahwa semakin lama tingkat 
devigorasi maka nilai delta akan makin besar. Hal ini diduga karena struktur kulit benih jenis-jenis tersebut yang cukup keras sehingga menyebabkan proses kerusakan benih menjadi lebih lambat.

Pada penelitian ini, nilai delta yang kecil didapat dari persentase bibit normal kurang kuat (KK) yang kecil dan persentase bibit normal kuat (K) yang besar serta bibit yang abnormal (A) cenderung kecil (Tabel 2) sehingga menghasilkan nila delta yang kecil. Oleh karena itu, penambahan jumlah benih per satuan luas sebanyak 49 butir tiap $600 \mathrm{~cm}^{2}$ mampu meningkatkan persentase bibit normal kuat $(79,27 \%)$ dan menurunkan persentase bibit normal kurang kuat (19,37\%). Bilman (2001) menjelaskan bahwa semakin tinggi tingkat kerapatan maka akan memacu penyerapan unsur hara, air dan cahaya antar tanaman dalam luasan tertentu. Tanaman akan menunjukkan laju pertumbuhan memanjang dalam usaha mengoptimalkan penyerapan cahaya matahari untuk keperluan fotosintesis. Parameter ini sangat penting untuk diketahui karena kecepatan tumbuh merupakan ukuran kunci dalam keberhasilan di lapangan (Anonim, 1983).

\section{KESIMPULAN}

Devigorasi benih Pinus merkusii sampai tingkat penderaan 240 jam dapat menurunkan vigor benih sampai 35\% terhadap kontrol (tanpa penderaan). Perbedaan kerapatan benih tidak berpengaruh nyata terhadap status vigor kecambah, nilai delta dan keberhasilan persemaian P. merkusii. Penambahan jumlah benih dengan peningkatan kerapatan untuk mengatasi penurunan vigor (devigorasi) benih masih dapat dilakukan pada semua taraf pengujian. Penurunan vigor benih tertinggi yaitu sebesar $35 \%$ terhadap kontrol masih dapat diatasi dengan peningkatan kerapatan benih 49 butir/bak kecambah untuk menghasilkan kecambah normal. Secara umum kecambah P. merkusii sampai umur 9 minggu masuk dalam kriteria normal (N) yaitu normal kuat $(\mathrm{K})$ dan kurang kuat (KK).

\section{DAFTAR PUSTAKA}

Abdul Baki, A.A and J.D Anderson. 1970. Viability and Leaching of Sugar from Germinating Barley. Crop Science, 10:31 34 .

Anderson, J.D. 1970. Physiological and Biochemical Differences in Deteriorating Barley Seed. Crop Science, 10:36 39 .

Anonim. 1983. Seed Vigor Testing Handbook. Contribution No. 32 To The Handbook On Seed Testing. Association Official Seed Analysis.

Anonim. 1985. SAS user's guide: Statistics, version 5 edition. SAS Institute Inc., Cary, NC.

Anonim. 2004. Kamus Biologi dan Teknologi Benih. Direktorat Perbenihan Tanaman Hutan. Direktorat Jenderal Rehabilitasi Lahan dan Perhutanan Sosial. Departemen Kehutanan. Jakarta.

Bilman, W. S. Analisisis Pertumbuhan Tanaman Jagung Manis (Zea mays saccharata), Pergeseran Komposisi Gulma Pada Beberapa Jarak Tanam. Jurnal Ilmu-Ilmu Pertanian Indonesia Vol. 3 No 1, 2001. Hal 25-30. www.geocities.com/ejurnal/files/jipi/2001/25.pdf. Tanggal 21 Desember 2006.

Blanche. C.A.; J.D. Hodges; A.E. Gomez and E. Gonzales. 1991. Seed chemistry of the Tropical Tree Vochysia hondurensis Sprague Forest Science Vol.37 No. 3:949-952.

Duryea, M. L. 1984. Nursery Cultural Practices : Impacts on Seedling Quality. Forest Nursery Manual : Laboratorium, Oregon State University, Corvallis. 143-145 pp.

Gardner, F.P., R.B. Pearce and R.L. Mitchell. 1991. Fisiologi Tanaman Budidaya (Terjemahan). Universitas Indonesia. Jakarta.

ISTA. 1996. International Rules for Seed Testing, Rules 1996. International Seed Testing Association (ISTA). Seed Science and Technology 24 (supplement). Zurich, Switzerland. 
Hamid, A. 2004. Penentuan Jumlah Benih Padi Sebar Langsung untuk Menekan Pertumbuhan Gulma. Buletin Teknik Pertanian Vol. 9 No. 1, 2004. Hal 1-3. Www.pustaka-deptan.go.id/publication/ bt091041.pdf. Tanggal 21 Desember 2006.

Kartika, E. 1994. Penentuan Kriteria Vigor Bibit serta Pengaruh Tingkat Devigorasi dan Kerapatan Benih terhadap Keberhasilan Persemaian Paraserianthes falcataria (L.) dan Acacia mangium Wild. Disertasi Program Pascasarjana IPB. Bogor. Tidak diterbitkan.

Kartiko, HP. 2000. Prinsip-Prinsip Umum Penanganan Benih Tanaman Hutan untuk Reboisasi, Penghijauan dan Hutan Rakyat. Ekpose dan Temu Lapang Hasil-Hasil Penelitian Perbenihan Tanaman Hutan. Denpasar 17-18 Oktober. Balai Teknologi Perbenihan. Bogor.

Rohandi, A dan N. Widyani. 2007. Pengaruh Tingkat Devigorasi dan Kerapatan Benih Krasikarpa terhadap Pertumbuhan Semainya. Jurnal Penelitian Hutan Tanaman Vol. 4 No. 1. Pusat Penelitian dan Pengembangan Hutan Tanaman. Bogor.

Sadjad, S. 1980. Panduan Pembinaan Mutu Benih Tanaman Hutan di Indonesia. Direktorat Reboisasi dan Rehabilitasi, Direktorat Jenderal Kehutanan - Lembaga Afiliasi IPB. Bogor.

Saptono, G. 1988. Hubungan antara Vigor Benih Pratanam dan Jumlah Benih yang Ditanam dengan Produksi pada Kedelai (Glycine max L. Merr.) Varietas Orba. Karil. Fakultas Pertanian, Institut Pertanian Bogor. Bogor. 46 hal.

Schmidt, L. 2000. Pedoman Penanganan Benih Tanaman Hutan Tropis dan Sub Tropis (Terjemahan). Kerjasama Direktorat Jenderal RLPS dan IFSP. PT. Gramedia. Jakarta. 530 hal.

Sutopo, L. 2002. Teknologi Benih. PT RajaGrafindo Persada. Jakarta.

Zanzibar, M. 2003. Kemunduran Viabilitas Beberapa Benih Pohon Hutan akibat Pengaruh Perlakuan Pengusangan. Buletin Teknologi Perbenihan Vol. 10 No.1. Badan Penelitian dan Pengembangan Kehutanan. Pusat Penelitian dan Pengembangan Bioteknologi dan Pemuliaan Tanaman Hutan. Bogor. 
Lampiran(Apendix) 1. Analisis keragaman pengaruh devigorasi dan kerapatan benih terhadap vigor kecambah dan keberhasilan persemaian P. merkusii (Analysis of variance to the effect of devigoration and seed density level on the sprout vigority an nursery success of P. merkusii)

\begin{tabular}{|c|c|c|c|c|c|}
\hline Parameter & $\begin{array}{c}\text { Sumber } \\
\text { Keragaman }\end{array}$ & DB & Jumlah Kuadrat & Kuadrat Tengah & F-hitung \\
\hline \multirow[t]{3}{*}{ Normal Kuat } & Antar Perlakuan & 5 & 488.193 & \multirow{3}{*}{$\begin{array}{l}97.639 \\
58.652\end{array}$} & \multirow[t]{3}{*}{$1.665 \mathrm{~ns}$} \\
\hline & Dalam Perlakuan & 12 & 703.826 & & \\
\hline & Total & 17 & 1192.019 & & \\
\hline \multirow[t]{3}{*}{ Kurang Kuat } & Antar Perlakuan & 5 & 531.458 & \multirow{3}{*}{$\begin{array}{r}106.292 \\
40.015\end{array}$} & \multirow[t]{3}{*}{$2.656 \mathrm{~ns}$} \\
\hline & Dalam Perlakuan & 12 & 480.181 & & \\
\hline & Total & 17 & 1011.639 & & \\
\hline \multirow[t]{3}{*}{ Abnormal } & Antar Perlakuan & 5 & 40.635 & \multirow{3}{*}{$\begin{array}{r}8.127 \\
25.434\end{array}$} & \multirow[t]{3}{*}{$.320 \mathrm{~ns}$} \\
\hline & Dalam Perlakuan & 12 & 305.210 & & \\
\hline & Total & 17 & 345.845 & & \\
\hline \multirow[t]{3}{*}{ Mati } & Antar Perlakuan & 5 & .000 & \multirow{3}{*}{$\begin{array}{l}.000 \\
.000\end{array}$} & \\
\hline & Dalam Perlakuan & 12 & .000 & & \\
\hline & Total & 17 & .000 & & \\
\hline \multirow{3}{*}{$\begin{array}{l}\text { Kecepatan } \\
\text { Tumbuh }\end{array}$} & Antar Perlakuan & 5 & 2.010 & \multirow{3}{*}{$\begin{array}{l}.402 \\
.213\end{array}$} & \multirow[t]{3}{*}{$1.886 \mathrm{~ns}$} \\
\hline & Dalam Perlakuan & 12 & 2.557 & & \\
\hline & Total & 17 & 4.567 & & \\
\hline \multirow{3}{*}{$\begin{array}{l}\text { Keserempakan } \\
\text { Tumbuh }\end{array}$} & Antar Perlakuan & 5 & 361.438 & \multirow{3}{*}{$\begin{array}{l}72.288 \\
83.430\end{array}$} & \multirow[t]{3}{*}{$.866 \mathrm{~ns}$} \\
\hline & Dalam Perlakuan & 12 & 1001.156 & & \\
\hline & Total & 17 & 1362.594 & & \\
\hline \multirow[t]{3}{*}{ Delta } & Antar Perlakuan & 5 & .000 & \multirow{3}{*}{$\begin{array}{l}.000 \\
.000\end{array}$} & \multirow[t]{3}{*}{$.212 \mathrm{~ns}$} \\
\hline & Dalam Perlakuan & 12 & .004 & & \\
\hline & Total & 17 & .004 & & \\
\hline \multirow{3}{*}{$\begin{array}{l}\text { Keberhasilan } \\
\text { Persemaian }\end{array}$} & Antar Perlakuan & 5 & 16.966 & \multirow{3}{*}{$\begin{array}{l}3.393 \\
4.680\end{array}$} & \multirow{3}{*}{$.725 \mathrm{~ns}$} \\
\hline & Dalam Perlakuan & 12 & 56.156 & & \\
\hline & Total & 17 & 73.121 & & \\
\hline
\end{tabular}

Keterangan $($ Remarks) $:$ ns = tidak berpengaruh nyata pada selang kepercayaan 95\% (insignificantly different at $95 \%$ confidence level) 